\title{
Energy and food demands, drivers of land grab; a case of Rufiji River Basin in Tanzania
}

\section{Energy and food demands, drivers of land grab; a case of Rufiji River Basin in Tanzania}

DOI: 10.5752/P.2317-773X.2017v5.n2.p121

Godfrey Eliseus Massay ${ }^{1}$

Recebido em: 15 de Agosto de 2017. Aceito em: 28 de Setembro de 2017.

\begin{abstract}
Land grabs has been a trendy phenomena in the last decade across the globe with Africa and Asia being the hard hit regions. There has been many drivers that fueled land grabs including the crises in the food, fuel and finance sector. Attempts have been made by scholars, activists and international communities to define what constitute "land grab" in the contemporary period. Informed by the framework definition of land grabs provided by International Land Coalition's Tirana Declaration of 2012, this paper uses two cases of foreign land-based agricultural investments to prove the existence of land grabs in Tanzania. Broadly, the two cases are evidence of the global energy and food crises shaping the national and local politics of land governance. These national and local politics are manifested into land grabs dispossessing communities of their land. The paper urges that there is direct link between the global and the national politics of land grabs. It further shows the role played and approaches used by social movements to resist land grabs.
\end{abstract}

Key Word: Land grabs; Energy; Food rufiji basin; Tanzania.
1. Godfrey Eliseus Massay is a land rights lawyer with over eight years of working experience with land rights civil society organisations in Tanzania. He holds Bachelor of Laws with honors (LL.B Hons) from the University of Dar es Salaam, Tanzania. He has written and published numerous articles in the area of land reforms, land-based investments, land disputes, social movements, and women's land rights. ORCID: orcid. org/0000-0003-2294-2309 
Introduction

Contemporary waves of large scale land acquisitions for commercial production in developing countries in Africa and other parts of the world have been branded as 'land grabs' by many scholars, media and activists. Some scholars have describe this phenomena as the "new scramble for Africa" (MOYO; YEROS, 2011). However, others have refuted such a description on the grounds that the current land deals are being negotiated by sovereign African states in the exercise of powers that they have under national laws (ODHIAMBO, 2011). The Land Equity Movement in Uganda defines a land grab as the accumulation of land holdings through illegal and or illegitimate means, or simply as deliberately and illegally taking away someone else's land rights (LEMU, 2009, p.1). This definition was qualified by Chambi and Baha (2011) as there are incidences whereby land acquisitions in light of the domestic policy frameworks and the legal system are sanctioned.

The most recent definition of a land grab was given by the Tirana declaration of the International Land Coalition, which says it involves acquisitions or concessions that are one of the following:

- In violation of human rights, particularly the equal rights of women;

- not based on Free, Prior and Informed Consent of the affected land-users;

- not based on a thorough assessment, or are in disregard of social, economic and environmental impact, including the way they are gendered;

- not based on transparent contracts that specify clear and binding commitments about activities, employment and benefits sharing, and;

- not based on effective democratic planning, independent oversight and meaningful participation (ILC, 2012).

The increasing quest for land in developing countries falls under the scope of the definitions given above and has been driven by food and energy demands, among others. Global demand for food, energy, raw materials, timber and conservation has resulted in huge acquisitions of land (over 203 million hectors of land) in Africa and other parts of the world. Studies have shown that $78 \%$ of global land deals have been for agricultural production, of which three quarters are for biofuels (energy) production (ANSEEW et al., 2012).

Tanzania, like many other countries in the Africa and other parts of the world has responded to the global rhythms and forces by allocating land for agricultural and energy production through both foreign and domestic direct investments and by reforming policies, legal and institutional frameworks to suit the changing dynamics of international trade and commerce. The Rufiji River Basin is one of the areas in Tanzania that has received many foreign and local investors in agriculture for food and energy production, for both local and external markets.

Most of the concessions in the Rufiji River Basin and other parts of the country are done in the name of investment, with the claim that 
foreign investments in land are beneficial to villages as they provide employment opportunities and employ inclusive agricultural business models which would also benefit small scale peasants and are thereby raising labor productivity in agriculture (KAMATA et al., 2012).

Land grabs are carried out today in the Rufiji River Basin through the application of both force and consent. In the case of the former, those to be dispossessed resist and when that happens they have to be coerced to comply. In the latter, the consent is used to dispossess after bombarding the dispossessed with illusions about a myriad of benefits from the investor. However, in both circumstances people resist either prior to acquisition of land or after (KAMATA et al., 2012).

In the subsequent parts of this paper, large-scale agricultural investment for food and energy will be examined, looking at how these investments fit in the description of 'land grab' provided above; the role of the state and its agencies in perpetrating land grabs will be underlined; and the impact of land grabs and the solution to curb it will be highlighted and proposed. Two case studies fitting in the description of land grab will be presented and discussed at length.

Background of land grab in Rufiji River Basin

The documented resource endowment of the Rufiji River Basin (RRB) here in after referred as RRB shows that it is one of the fourteen basins in Tanzania and one of the biggest. The RRB covers an area of 176,000 sq. km, and consists of Rufiji Delta, the Luwero, Kilombero and Ruaha rivers. It is the biggest river basin in Tanzania and drains about $20 \%$ of the country. It is the most ecologically and biologically diverse, and socially and economically important wetland. It supports a gallery of ecosystems ranging from forests, sand dunes, beaches, and ocean; as well as exotic plant and animal species - some of which have been declared endangered (KAMATA et al., 2012). The area is naturally endowed with fertile soil and a variety of potential investment attractions including wildlife and forests. For that reason, it is home to all sorts of interests and motives, both good and bad (HAKIARDHI, 2012).

The richness of RRB in resources was recognized during pre-colonial time by European explorers in 1880s; Elton said "it is a land of plenty" and Joseph Thomson said "it is extremely favorable country". During the colonial period Germans introduced cotton farming, which caused the Maji Maji war between 1904-1907 in which about 300,000 people lost their lives and the British had the plan to install hydro-electric power generation. In 1975, post-independence Tanzania established the Rufiji Basin Development Authority (RUBADA) with a view to developing the Stigler dam, which would generate hydroelectric power. The controlled water would also be the source of a large irrigation project, able to feed the rest of the country as well as some other African states. This plan never materialized (KAMATA et al. 2012).

In 1996 the joint efforts of indigenous people in the delta - researchers, academicians, lawyers, journalists and environmental activists - man- 
aged to halt an attempt by government and foreign investors to acquire about 19,000 hectares of land, which would include mangrove forest for the purpose of prawn farming. This project would have caused serious ecological and ecosystem effects in the delta.

Tanzanian policy and legislative reforms in the 1990s that responded to the liberalization policies spearheaded by World Bank and IMF have made Tanzania an attractive place for investment. The search for the African green revolution through the Comprehensive African Agriculture Development Programme (CAADP) of the New Partnership of Africa's Development (NEPAD) and Alliance for a Green Revolution in Africa (AGRA); and national initiatives toward a green revolution through the Agricultural Sector Development Programme (ASDP), commercialization of agricultural sector through the Southern Agricultural Corridor of Tanzania (SAGCOT) and Kilimo Kwanza (Agriculture First Initiative) have made RRB one of the strategic areas to implement these policies in the name of alleviating poverty from the poor masses.

This shows how the desire of the government of the United Republic of Tanzania to welcome interested partners coincided with the global demand for land for both food and biofuel productions. Forces from outside Africa, within Africa and within Tanzania are looking for chunks of fertile and irrigable land to meet the demands for food and energy within and outside Tanzania. RRB has been flooded with investors because it has all it takes for agriculture to flourish. There are over 14 foreign investors who have acquired thousands of hectares of land with the support from state actors such as district land officers, legal officers, district commissioners, the Minister for Lands, members of the parliament, and through state agencies like the Tanzania Investment Center and RUBADA.

At the onset it is important to note that RRB falls under multiple jurisdictions which in itself is a source of land use conflicts between the various land users. For instance, the whole basin is managed by RUBADA while within it there are villages that fall under the local government authorities, and the Selous Game Reserve and Eastern Arc Mountain are under Ministry of Natural Resources. Each authority has its own mandate without a coordinating agency. This makes administration of justice difficult and the land use conflicts inevitable (HAKIARDHI, 2012).

The fact that the term 'land grab' irritates the ears of politicians, government officials and investors needs not to be overstated. Between 2011 and 2013 some high ranking politicians in Tanzania such as the then Prime Minister and the then Minister for Lands publicly refuted the term land grab to the extent of calling it "a myth". Similarly, the International Land Coalition, in its 2011 study (ANSWEEW et al. 2012), carefully avoided the term "land grab" and used "land rush" instead. We believe there is no need to refrain from the use of this term for there is no other better terminology to describe the phenomena. In the next part, two foreign companies that have invested in RRB will be examined in the light of the description of a land grab and the role played by state actors and agencies in facilitating the process. 


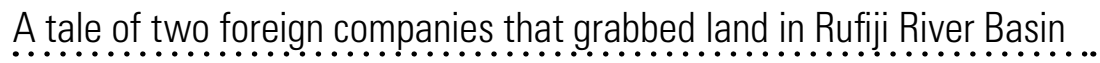

There is much foreign direct investment in RRB but for purpose of this paper, two companies have been selected: one that engages in agricultural production for food and another that involves in agricultural production for biofuels (energy).The companies were purposely chosen to include only those that have invested in RRB in agricultural production for food or energy to meet demands for food and energy security. SAP Agriculture Ltd, a Turkish company herein after referred as SAP and African Green Oil Company, United Kingdom (UK) based company, here in after referred as AGO have invested in food (paddy and maize) and energy (palm oil) respectively.

Between 2005 and 2006 SAP acquired 5000 hectors of land in Nyamwage villages in RRB. The process of land acquisition was marred with directives from top government officials to district and village officials. In 2005 the Tanzania Investment Center (TIC) approached Nyamwage and Ikwiriri South villagers via Rufiji District Council, requesting 5,000 hectares on behalf of SAP. District Executive Director (DED) received application for land from the TIC on behalf of investors who had been cleared by government to invest in farming in Rufiji. Part of the letter written by DED to village leaders of Nyamwage and Ikwiriri South states "with this letter I am requesting you to release the land in order to speed up the district's development and that of the country in general" (letter dated 21.02.2005 as cited in KAMATA et al. 2012). The same letter went further to state that the investor would grow paddy and maize and directed that the decision on the matter should be reached before $25^{\text {th }}$ February 2005. These two villages had hardly a week to comply and not to have enough time to dialogue, negotiate, and decide.

Villages in Nyamwage and Ikwiriri South had great expectations about the new investor SAP after they were hypnotized with many promises made by investor such as: to build a secondary school in the village, to build a house for a village clinical officer, to improve the village water project by bringing about more powerful machines since the existing one was small, to construct a police post, to supply electricity to the village and to assist those with farms.

Villagers were assured by the district officials, acting on behalf of the investor, that their request would be granted (Nyamwage village minutes). This was like a dream come true to these villagers, who expected that investors could extricate them from the grip of poverty. One of the leaders was quoted as saying "if investors come we would benefit because they will bring capital and enable us to irrigate our farms" (KWEKA, 2012). What will follow after this amazing first encounter? Hopelessness and desperation.

In 2006 AGO was registered in UK. This is based on an unconfirmed source (cited in KAMATA et al. 2012) that says the company requested and acquired land for biofuel production in RRB in 2007. This was the time when the hype for biofuel was surfacing in Tanzania because it was after the German Organization for Technical Cooperation (GTZ )report of the country - wide study on the potentials for biofuel 
production was just released. The report recommended that the government should start "immediately and without waiting for results and policy advice from the Task Force, to promote increased use of biofuel through the learning-by-doing process" (GTZ 2005). This was taken at the heart of government by top government officials, as evidenced in the statement given by the then Prime Minister of Tanzania, Hon. Edward Lowassa, in which he said;

\begin{abstract}
With the continued rise in global demand for fuel and consequently the upward pressure on oil price, biofuels are increasingly becoming alternative fuel sources. In Tanzania we have plenty of land for growing the relevant crops. We are, therefore, keen to see further investments in palm oil, jatropha, sugar for ethanol and we welcome interested partners (KAMATA et al. 2012).
\end{abstract}

Like SAP, AGO was introduced to villages by government officials. In Nyamatanga village a letter from the district office, dated 7/6/2007 introduced the investor AGO to the villagers (Nyamatanga, Rwaruke, Rungungu and Nyanjiti). The letter stated that "the district office has received the investors request for land and that the district is directing to these villages because there is land". The letter also introduced that "the investor must be accompanied by an officer from the district council when going to the village" (KWEKA, 2012).

In Nyamatanga a district expert attended a meeting to discuss the request for land by the investor. The officer was asked questions and answered on behalf of the company (minutes of special meeting of $7 / 7 / 2007$ ). Based on this, villagers were satisfied and agreed to give land and left the district to decide on the amount of the rent (Village letter to the District Executive Director dated 7/7/2007). Minutes on 12/11/2007 reported that villagers approved the land for the investor (KWEKA, 2012).

Villagers were lured by the investor and they identified health, education, water, milling machines and road services for the company to support in return for the land. It was reported that villagers thought that the company would help them to conduct modern agriculture and provide market for their produce and increase their income (KWEKA, 2012).

Nyamatanga villagers wanted to know the size of land they gave to investor but they were bypassed during the process of surveying the land. As a result they refused to sign the contract. A field visit of some Swedish researchers has established that the company acquired 200ha in Nyamatanga village and 80 ha in Rungungu village (LINDA, 2012; MASSAY, 2012) and a study by Hakiardhi (2013) indicate that the investor acquired 3,500ha in four villages (Lungungu, Nyamatanga, Kilulwetambwe, and Nyanjiti). With these discrepancies on data one would guess what will happen in future. Wonders!

SAP developed 700 ha of land in 2005 followed by 600 ha in 2007 and since then no farming has been taking place. Five years after the land was acquired none of the promises had been fulfilled, no compensation has been paid to the village and people whose land was taken and the investor is nowhere to be seen. Villagers were disappointed by this development and they were further frustrated by the restrictions imposed by the company for them to access fishing ponds located in the same land allocated to the company. 
Some of the reasons why the villagers in Nyamatanga refused to sign contract with AGO are: they did not know the size of the land, some individuals have not been compensated for their land, low payment for those employed by the investor in the farm and poor working conditions (KWEKA, 2012). The investor left saying "we failed to invest with profit" (LINDA, 2012, MASSAY, 2012).What actions were taken by villagers in response to what was done to them by these companies?

Villagers did not just sit and wait for miracles to happen, they took action. In 2008, Nyamwage village government sent a letter to the district authority requesting them to take over their land because the Turkish investor was nowhere to be seen. In the letter to the Permanent Secretary of the Ministry of Land and Human Settlement Development the chairman of the village stated two reasons for having their land back, namely: no compensation was paid and the land was not developed since 2005. Prior to this official correspondence villagers decided to vent their frustrations by serving themselves with what was in the farm (KAMATA et al. 2012).

Villagers in Nyamatanga village complained about the investor AGO not fulfilling their demands and they refused to sign the contract (minutes of the emergency meeting held on 28/9/2009). A village officer went and spoke about the issue over the radio and showed the contact to a lawyer (his friend) for help. After all these what was the reaction of the State to its people? Unbelievable! Shocking!

The village leaders of Nyamwage village never received feedback of their letters from the district authority and permanent secretary. The state turned deaf ears on the complaints leveled against the investor. The village officer who went to the media (radio) was arrested and put into police custody for two days by the district office. He was charged with "exposing the government's document (contract) and violating decisionmaking levels". One would wonder if this was the same government that was assisting the investor to get land by seeking villagers' consent. Based on these facts, I join Kweka (2012) who argued that, unfortunately, state intervention in investment in Tanzania is strong in supporting investors to get land and little assistance is given or response or action taken to assist villagers in their demands or in ensuring investors fulfill their promises. This reminds me of the late Ben Lobulu, an advocate who defended the interests of small producers against land dispossession in Tanzania in courts and in his writings. He once wrote;

Pressure of land is increasing by leap and bounds. Infringing on customary land rights continues at fevered pitch. Professional hunters, mineral prospectors, commercial farmers, those who hunger for the Canadian wheat, and foreign adventures reminiscent of, and encourage by the spirit of Christopher Columbus, Ferdinand Magellan, and Marco Polo are on the rampage. Pastoral land is fast disappearing, and why not, if parks, graveyards, school playgrounds could be, and have been expropriated? This land grabbing mania is fuelled by politicians and their lackeys who are in the business of lining their pockets. They find ready support from a civil service that is bereft of professional ethics and morality and which readily sell its conscience in return for the biblical 30 pieces of silver (LOBULU, 1998; Maina, 2007; HUMAN..., 2012)

Sentiments of disappointment in Nyamwage when they realized that SAP was sold to Maji ya Chai Company are in this statement from 
their leader: "we thought investors would be the answer to our capital needs, but now we know there is nothing to that end. When they come they have good words written on paper but in reality they are con-men". Interestingly, even government officials in Rufiji said "most of the investors were not genuine; when they come they presented big and ambitious plans but once successful in acquiring land they do not do much". In Nyamatanga villagers are of the view that investment has divided them, brought tension in the village, with some villagers blaming those who accepted the investment in the first place.

Verifying evidence of land grab

It is quite clear based on the facts presented about the two companies (SAP and AGO) that have invested in RRB that, both companies violated principle of Free, Prior and Informed Consent in land acquisition because villages were given short time to accept the investment without been guaranteed of their land rights through binding agreement. They did not respect human rights, by failing to provide compensation and by violating labour rights. Though the projects proved to be unstable, villagers were denied their land back. In other situations, the state operates as shield for investors against the people; this was evident when the "Regional commissioner ordered villagers to comply with the directives to release land to the investor otherwise they (villagers) would be blacklisted, and the government would not support any development efforts in their villagers. This was specifically said in relation to Ruwe village which, of all villages in RRB, is epitome of opposition of RUBADA project" (KAMATA; MWAMI 2012). What then is the better terminology to describe this unspeakable tendency than land grab?

Recommendations

To curb land grabbing in RRB the following recommendations need to be taken in to consideration seriously: First, there is need for a comprehensive land use plan in all villages within the basin. Tanzania currently has about 12,545 villages and statistics shows that only 1731 villages have been surveyed and planned (RASIMU..., 2017). Land use plans can help villages to know the size of their village land and plan for their current land use and the land for future generations. With a village land use plan, villagers can identify land to be leased to potential investors. Nyamatanga village did not sign the contract with investor because they did not know the size of land. Not signing the contract, however, did not stop investor from using the land because the current legal system does not make it a mandatory requirement. Approval of the villagers, which is evidenced by minutes of village assembly meeting, is what law provides as the mandatory requirement.

Second: land has to be given a constitutional protection. A 40 yearold constitution of the United Republic of Tanzania, which was promulgated in 1977 and which underwent fourteen amendments, is numb about land and land-based resources. This is the biggest challenge because the 
current land legal regime, which is governed by Land Act and Village Land Act (both of 1999) has centralized more powers to the government. These land laws declare all land in Tanzania as public vested under the President as the trustee. The laws allow acquisition of any piece of land by the state for public interest, which can be investment for public interest. The definition of the term public interest has not been clearly defined by these laws. The laws do not allow foreigners to own land save for investment purposes. It is quite clear the drafters of land laws have made land acquisition for investment easy because state can acquire land at any time on the grounds that it is needed for "investment for public interest". Constitution that can guarantee land rights and provide for independent land commission and procedures of land acquisition for investment can provide better solutions to the existing land tenure problems.

Third: transparency in land deals. It is important that all land deals to be entered through transparent processes and for such documents to be made public for scrutiny, accountability and follow-ups. The practice shows that it is hard for one to get hold of them; when you visit the authorized institutions (government departments and agencies) one is viewed with skepticism and is subjected to bureaucratic red tape. A village officer in Nyamwage village was terrorized by district officials because such documents are classified or confidential. It has become so hard for researchers to get accurate data on land concessions in the country because of confidentiality around such deals.

Fourth: Land rights awareness - raising programmes. Villagers in $\mathrm{RRB}$ and those who are in other parts of Tanzania need to be made aware of their land rights and the laws that protect them. This will help them to advocate and defend for their land rights whenever efforts are being made to take their land away. The programme will also help villagers to understand their powers through the village assembly, which can help them to negotiate well before entering any land deal and to hold their government accountable. The efforts of NGOs such as HAKIARDHI that have reached nearly 1000 villages in Tanzania with this programme need to be supported.

Fifth: strengthen the capacity of local institutions. The Village Land Act of 1999 vests administrative powers of village land under the village council. Village land is one of the three categories of land in Tanzania; others are general and reserved land. Village land is composed of $70 \%$ of all land in Tanzania but is governed by a village council, which is a corporate body with trusteeship powers. This body is composed of not more than 25 members who are villagers, the majority of them with minimal primary school education. They are not educated, hence most of them do not understand what their powers and limitations as provided by laws are. On many occasions they have been manipulated by politicians, government officials or unscrupulous elites. Strengthening their capacity through their knowledgebase on land rights and governance can help them to fight forces from outside that eye their land and negotiate for the interest of their village. HAKIARDHI has experience on this and there is much evidence to prove how this has worked in certain villages in Tanzania. 
Sixth: Leadership with integrity. I am not sure if integrity can be bequeathed through education, but if we have leaders in the government and political parties who have integrity then RRB would have been the land of milk and honey in Tanzania. We need leaders who take the interest of their people and country before anything else; leaders who are accountable, transparent, respect rule of law and human rights; and those who respect democratic governance and fight for corruption. There is a leadership gap which needs multifarious efforts to fill it. The evidence of it is when a leader clearly knows that what he/she is doing is against the laws and will affect the livelihood of many people, yet he proceeds in doing it for his/her interest or that of his/her instructor.

Concluding remarks

In Tanzania, government officials and politicians have repeatedly, in public, (mostly in investment meetings or any occasions of inaugurating FDI or investment projects) decried those who say there is land grabbing in the country as mockers of the efforts taken by the government to alleviate its people from poverty. There is no country in this world which has prospered without investment; it does not need a genius to figure this out. But what kind of investment can lead the country to develop? Can the two companies discussed above help Tanzanians to develop or under develop?

We want the investments that adhere to the principle of free, prior and informed consent; the ones that integrate the local communities to their projects and make them the one of owners of the project; the ones that do not take advantage of a weak legal system, ignorance, and the poverty of the people for their prosperity. This will help Tanzania to develop and alleviate its people from abject poverty.

There are mega projects in agricultural sector that will be implemented in SAGCOT regions (covering 300,000 sq. $\mathrm{km}$ ) in the near future in Tanzania. Will they be the reminiscent of the two companies discussed above, and should we keep quiet if that happens? Posterity will judge us for our actions today. We should learn from history to project and plan for better future.

Reference

ANSEEUW, Ward et al. Land rights and the rush for land: findings of the global commercial pressures on land research project. Rome: ILC, 2012.

CHACHAGE, C and BAHA, B. Accumulation by Land Dispossession and Labour Devaluation in Tanzania; The Case of Biofuel and Forestry Investments in Kilwa and Kilolo. Hakiardhi. Dar es Salaam. 2011.

CHAMBI, C and Baha. Accumulation by land dispossession and labour devolution. HAKIARDHI. 2011. Disponível em: <http://www.hakiardhi.org/index.php?option=com_ docman\&task $=$ doc_download $\&$ gid $=102 \&$ Itemid $=80>$.

GTZ (German Technical Cooperation). Liquid Biofuels for Transportation in Tanzania: Potential and Implications for Sustainable Agriculture and Energy in the 21st Century. 2005. Available at: <http://www.globalbioenergy.org/uploads/media/0508_GTZ_-_Liquid->

HAKIARDHI. Annual Report for the Year 2011/2012. HAKIARDHI, Dar es Salaam. 2012 
HAKIARDHI. Biofuels in Tanzania: small scale producers and sustainable environment management. Dar es Salaam: HAKIARDHI, 2013. Disponível em: <http://www.hakiardhi.org/ index.php?option $=$ com_docman $\&$ task $=$ doc_download $\&$ gid $=1768$ Itemid $=80>$. Acesso em: 09 nov. 2017.

ILC. Tirana Declaration: "Securing land access for the poor in times of intensified natural resources competition”. ILC. Tirana. 2012. Available at: $<$ http://www.landcoalition.org/sites/default/files/documents/resources/tiranadeclaration>.

KAMATA, Ng'wabza; MWAMI, Abunuwasi. Land grabbing in the post investment period and popular reactions in Rufiji River basin. Dar es Salaam: Hakiardhi, 2012. Dispon $<$ http://www. hakiardhi.org/index.php?option=com_docman\&task=doc_download\&gid=155\&Itemid=80>.

KWEKA, Opportuna L. On whose interest is the state intervention in biofuel investment in Tanzania? CSCanada, v. 8, n.1, 2012.

HUMAN rights and business in Tanzana; stock taking of labour rights, land rights, environmental justice and consumers rights protection. Dar es Salaam: LHRC, 2012.

LEMU (Land Equity Movement in Uganda). Let's face Up to Land Grab. LEMU. Kampala. 2009. Available at: <http://www.land-in- uganda.org/assets/LEMU-Lets- face-up- to-Land- Grabbing-2009.pdf>.

LOBULU, Ben. Dispossession and land tenure in Tanzania: what hope from the courts? [S. 1.]: Cultural Survival, 1998.

MAGHIMBI, Sam; LOKINA, Razack; SENGA, Mathew. The agrarian question in tanzania: a state of art paper. Current African, n. 45, 2011.

MASSAY, G. Biofuels and Land Issues in Tanzania. [S. 1.]: PISCES. 2012

MOYO, S and YEROS, P (Eds). Reclaiming the Nation: The Return of the National Question in Africa, Asia and Latin America. New York: Pluto, 2011.

OTHIAMBO, Michael Ochieng. Commercial pressure on land in africa; a regional overview of opportunities, challenges and impacts. Nakuru: ILC. 2011. Disponível em: $<$ http://www. landcoalition.org/sites/default/files/documents/resources/Africa\%20Overview $\% 20 \mathrm{WEB} \% 20$ 14.07.11.pdf>. Acesso em: 10 nov. 2017.

RASIMU ya Mkakati wa Kukabiliana na Changamoto za Matumizi Bora ya Ardhi Nchini. Tume ya Taifa ya Mipango ya Matumizi ya Ardhi. Dar es Salaam: URT, 2017. 